\title{
Current Causes of Girls' Low Performance in Physical Sciences from Hard-to-reach Secondary Schools in Eastern Uganda
}

\author{
Jalira Namugaya ${ }^{1,2}$, Isaac Habumugisha ${ }^{3,4,5, *}$ \\ ${ }^{1}$ Department of Mathematics, Muni University, Arua, Uganda \\ ${ }^{2}$ Institute for Basic Sciences, Technology and Innovation, Pan African University, Nairobi, Kenya \\ ${ }^{3}$ Department of Physics, Mbarara University of Science and Technology, Mbarara, Uganda \\ ${ }^{4}$ Department of Physics, Islamic University in Uganda, Mbale, Uganda \\ ${ }^{5}$ Department of Physics, Kabale University, Kabale, Uganda
}

Email address:

jaliran08@gmail.com (J. Namugaya),hisaac08@yahoo.co.uk (I. Habumugisha)

${ }^{*}$ Corresponding author

\section{To cite this article:}

Jalira Namugaya, Isaac Habumugisha. Current Causes of Girls' Low Performance in Physical Sciences from Hard-to-reach Secondary Schools in Eastern Uganda. International Journal of Secondary Education. Vol. 5, No. 1, 2017, pp. 12-15.

doi: $10.11648 /$ j.ijsedu.20170501.12

Received: October 28, 2016; Accepted: December 22, 2016; Published: February 22, 2017

\begin{abstract}
Physical science, a branch of science is concerned with nonliving matter and energy such as physics, chemistry, and astronomy. Ideally, everyone would excel in this area of science, because it is a basic science. In Uganda, hard-to-reach areas exhibit high rates of poor performance at secondary level and it is quite alarming on the side of girls offering science subjects. In this paper, we present the current causes of high failure rates. 130 Students, teachers and head teachers from ten schools in two districts of Manafwa and Bududa in the Eastern part of Uganda participated in the study. The major cause on the side of students is lack of role models and mentors whereas for the teachers, it is attributed to background knowledge of science. On the contrary H/teachers assert that high failures rates are due to economic factor which keeps students' minds absent. We suggest that counseling and guidance by senior female scientists can change this situation.
\end{abstract}

Keywords: Low Performance, Physical Sciences, Hard-to-Reach, Secondary Schools

\section{Introduction}

The term 'hard-to-reach secondary school' is a phrase used to describe communities that struggle to access health care, education and other basic services [1]. According to the Government of Uganda, hard-to-reach areas are those that are remote, insecure, have poor infrastructure, suffered prolonged conflicts, and some are surrounded by water bodies or are mountainous. The Eastern part is one among such places. These areas are characterized by prevalence of poverty, high illiteracy and school dropout levels. In these hard-to-reach schools, the poor results in science achievement reflect a general panorama of poor academic performance [2].

In 2007, Uganda became the first Sub-Saharan country to start a scheme of Universal Secondary Education (USE). This scheme has considerably increased public secondary school enrollments especially for girls from poor households [3]. However, the number of girls reaching university taking science careers has remained minimal due to failure rates. To avert this, the government adds to every female student 1.5 points on the weighing system but alas the ratio is never $1: 1$ in any of the physical science courses for any university.

This raises to a series of questions for science educators, educational leaders and policy makers: We ask first, why has this remained the case? What are the causes for the high failure rate? High failure rates in secondary level science classes are a problem worldwide [4]. This in turn has attracted the interests of many researchers internationally [4] 
and in the region (Africa) [5, 6, 7, 8].

Recently, [7] investigated factors affecting the performance of secondary school students in chemistry. The study revealed that factors like attitude/interest, previous preparation, study style, parental involvement and teacher expectancy influence students' performance in chemistry in Kolokuma/Opokuma local government area of Bayelsa State.

These findings are similar to those of [8], for a study conducted in Azare Metropolis of Bauchi State, Nigeria to establish the causes of poor performance in Mathematics among Public Senior Secondary School Students. Their findings of the study led to the conclusion that students' negative attitude towards mathematics, anxiety and fear of mathematics, inadequate qualified teachers, poor teaching methods, inadequate teaching materials, overcrowded classes were some of the causes of poor performance in mathematics in the study area.

The purpose of this study is to determine the current causes of low performance of girls in physical sciences in hard-to-reach secondary schools in Eastern Uganda.

\section{Methodology}

\subsection{Study Area and Population}

Two districts; Bududa and Manafwa were purposely selected from Eastern part of Uganda. This was because some parts of these districts are classed as hard-to-reach and have recorded high failure rates in regional and national exams. The two are neighbouring districts. According to the 2014 census [9], Bududa District has a population of 210 , 173 people with $105,820(50.3 \%)$ males and 104,353 $(49.7 \%)$ females. It covers an area of 250.8 square kilometers. The coordinates of Bududa town are $01^{\circ} 00^{\prime} 36.0^{\prime \prime} \mathrm{N}, 34^{\circ} 19^{\prime} 54.0^{\prime \prime} \mathrm{E}$ (Latitude: 1.010011; Longitude: 34.331663). On the other hand, Manafwa district has a population of 353,825 people of which 173, $580(49.1 \%)$ males and 180,245 (50.9\%) females. The total land area of the town is approximately 602.1 square kilometers. The coordinates of the Manafwa central town are $0^{\circ} 55^{\prime} 11.0^{\prime \prime} \mathrm{N}$, 34¹7'28.0"E (Latitude: 0.91972 3; Longitude: 34.291099).

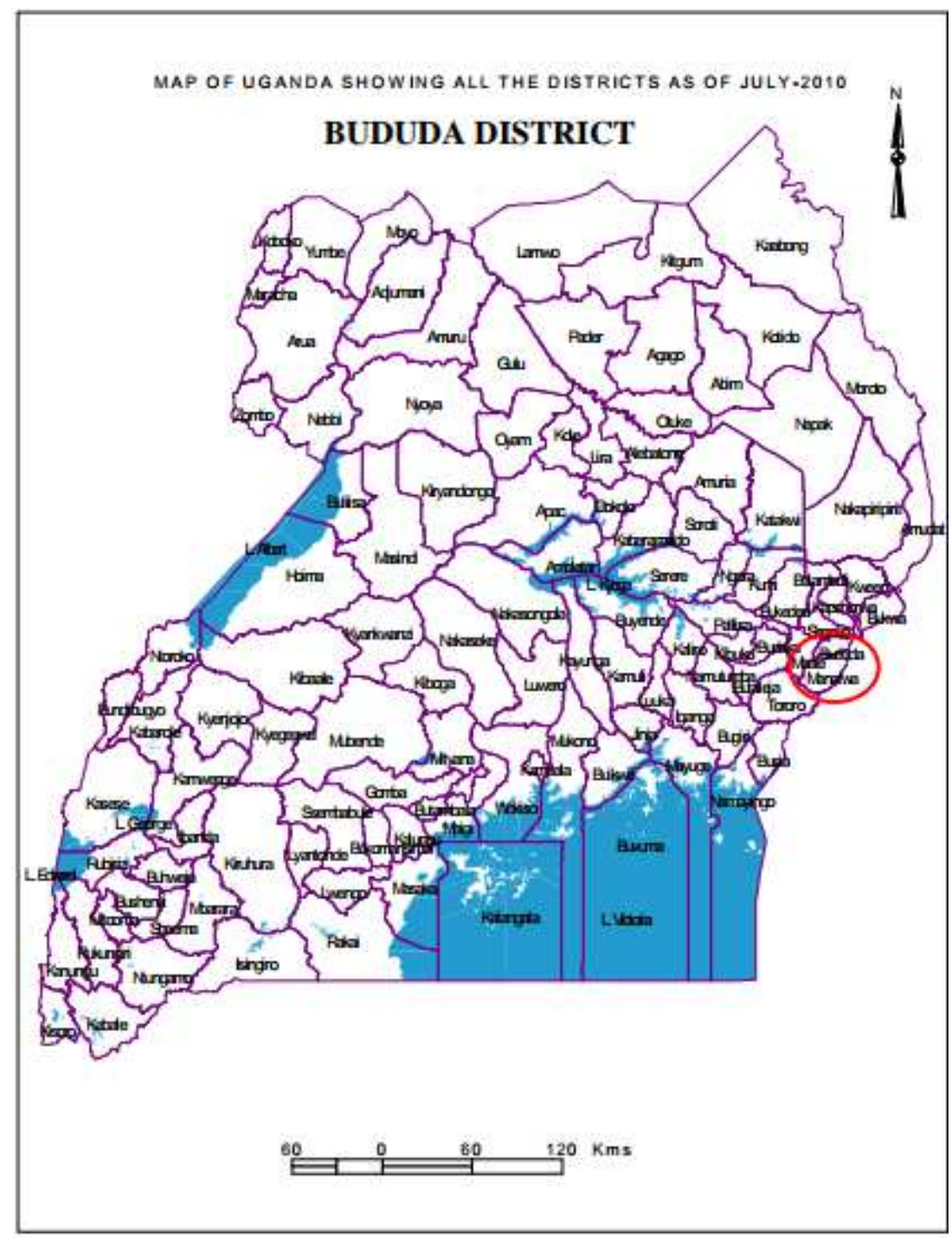

Figure 1. Map of Uganda showing Districts of Bududa and Manafwa as of July 2010, [10]. 
Due to the volcanic fertile soils, the major economic activities in both districts includes but is not limited to crop and animal farming and trade, trade in retail and wholesale of agricultural products.

\subsection{Data Collection}

From the two districts, data was collected from 130 respondents. Each district had a 50\% contribution with students $100(77 \%)$, teachers $20(15 \%)$ and $10(08 \%)$ were head teachers. Of the students $80(80 \%)$ were girls while 20 $(20 \%)$ were boys. Boys were included in this survey because they provided crucial information since they attend class together with the girls.

Both qualitative and quantitative data was collected. Qualitative data was transcribed, and was cross-tabulated to show the different variables. After which it was analyzed using Mathematica-11 software. This generated numerical values required in this study.

Two methods were mainly employed in primary data collection. These are in-depth interviews and questionnaire methods. The interviews were designed for teachers and head teachers who could not find time for questionnaires and beside the interview questions were designed suitably to obtain information that wouldn't be obtained by administering a questionnaire. These questions were both structured and unstructured.

\section{Results and Discussion}

\subsection{Results}

The study findings from the districts of Bududa and Manafwa are shown in Table 1. All the 130 respondents participated. Each response was expressed as a percentage of all the responses in either category (students, teachers and head teachers).

Table 1. Causes of girls' low performance in physical sciences.

\begin{tabular}{lll}
\hline Respondent & Cause & Percentage (\%) \\
\hline \multirow{3}{*}{ 1. Students } & (a) Lack of role models and mentors. & $100 \%$ \\
& (b) Lack of space for practicals & $70 \%$ \\
& (c) Late syllabus coverage & $65 \%$ \\
& (a) Over population in class & $100 \%$ \\
\multirow{5}{*}{ 2. Teachers } & (b) Background knowledge & $80 \%$ \\
& (c) Absenteeism and late coming & $60 \%$ \\
& (a) Poverty & $100 \%$ \\
& (b) Over population in class & $99 \%$ \\
& (c) Absenteeism and late coming & $70 \%$ \\
\hline
\end{tabular}

Source: Field data

\subsection{Discussion}

Lack of role models and mentors; This was cited as a leading cause of failure. Over the years, in such hard-to-reach communities females have always been taken as housekeepers as soon as they perfects doing home assignments. In the short run some girls in these hard-to- reach areas will opt out of school for marriages. This is partly why there are few female scientists who have taken up science careers and can act as role models.

Students also attribute the cause of failure to lack of space for practicals which leads to no practical sessions. They further cited that they have seen practicals arranged for their colleagues only in the final year towards national examinations. To make matters worse, during this session, only an overview of practical techniques are addressed leaving students to enter the exam room with no skill. It is for this reason that the end result has been a failure. In one of the schools, the researchers established that, in a certain academic year $100 \%$ of the students failed a physical exam.

Syllabus coverage was next with a high rating as a cause of failure; our inquiry showed that year 1, 2, and 3 of secondary study are truly lagging behind in terms of coverage as compared with the general teaching syllabus. It was confirmed from some of the head teachers that besides running a theoretical dominated curriculum, the syllabus was not completed in time.

Poor record keeping; specifically, the researchers got interest in this cause after observing the whole physical science environment at school. Most of the students being in day section, carry few books to school and in some instances one book can be used for more than two subjects. A big number of girls in the final year have fragmented records of work covered. This has a great impact on the final grade in final exams.

On the side of heads of schools, poverty was the cause of failure. To them, this has an indirect effect on girl child's performance. They revealed that lack of basic scholastic materials had on many occasions led girls to abandon school forcing them to opt for hard labor and early marriages.

Over population was greatly cited by both head teachers and teachers. In some areas we found one secondary school serving a whole community with a teacher to student ratio per stream about 1:80. To this teachers were found of improvising with methods that are not suitable for physical science teaching. There was no numerical exercise given at the time the survey was conducted to the respective schools. Further, in previous study sessions less than $10 \%$ of class work exercises were followed up by the teacher. This leaves the girl child unattended to and as a result, she lags behind understanding cores of physical science.

According to teachers, background knowledge was a cause of failure. Poor grades from primary level hamper girls from catching up in secondary level physical science.

Finally, absenteeism and late coming to school was cited as a cause of low performance. Due to the nature of the terrain, students' attendance was not regular. Our observations revealed that absenteeism and late coming to school are not checked by school administrations. Most schools were not fenced and had no gates, leaving open doors to access school any time. To this, some girls were open to reveal that, sometimes they are requested to do gardening before setting off for school. In this case, some of the 
students who walk long distances back home were excused to go home early.

\section{Suggestions}

We recommend that the government and other stake holders should come-up with a more comprehensive incentive scheme to attract teachers to hard-to-reach schools. Career guidance for the girl child should be given priority.

\section{Conclusion}

The causes of low performance most especially on the side of girls in physical sciences (physics, chemistry, and astronomy) in hard-to-reach secondary schools need to be identified. This is because of the dire need for everyone to be able to answer questions around the physical properties of our surrounding in this universe. In this study, we find out that at the start of secondary, girls and boys have the same footing. But later, girls lose the grip due to factors which have an economic, cultural, and social background. Without addressing these problems, it is the girl child who will continue to lose careers in physical sciences. We hope that this information can be helpful to local and national education stakeholder plus international Non Governmental Organizations (NGOs) that are interested in helping the girl child in education.

\section{Acknowledgements}

We are grateful to our colleague, S. Bodio for taking time to read through the original manuscript.

\section{References}

[1] Crozier G. and J. Davies. Hard to reach parents or hard to reach schools? A discussion of home-school relations, with particular reference to Bangladeshi and Pakistani parents. British Educational Research Journal. Vol. 33, No. 3, 2007.
[2] Uganda National Examinations Board (UNEB) report 2016.

[3] Asankha P. and Takashi Y. Impacts of Universal Secondary Education Policy on Secondary School Enrollments in Uganda. Journal of Accounting, Finance and Economics. Vol. 1, No. 1, 2011.

[4] Fonseca J. M. B. and J. E. Conboyv. Secondary student perceptions of factors effecting failure in Science in Portugal. Eurasia journal of mathematics, science and technology education. Vol. 2, No. 2, 2006.

[5] Anthony, G. Factors influencing first-year students success in mathematics. International Journal of Mathematical Education in Science and Technology. Vol. 31, No. 1, 2000. Pp 3-15.

[6] Mbugua Z. K., Komen K. G. and Nkonke G. K. Factors Contributing To Students' Poor Performance in Mathematics at Kenya Certificate of Secondary Education in Kenya: A Case of Baringo County, Kenya. American International Journal of Contemporary Research. Vol. 2, No. 6. 2012.

[7] Imomotimi. E. and Vikoo E. Some Factors Affecting the Performance of Secondary School Students in Chemistry, A Kolokuma/Opokuma Study. Journal of Education and Practice. Vol. 4, No. 7. 2013.

[8] Sa'ad, T. U., Adamu A. and Sadiq A. M. The Causes of Poor Performance in Mathematics among Public Senior Secondary School Students in Azare Metropolis of Bauchi State, Nigeria. Journal of Research \& Method in Education, Vol. 4, Issue 6. 2014, pp 32-40.

[9] National Population and Housing Census 2014 Report (Eastern Region).

[10] Google (7 July 2016). Map showing location of Manafwa and Bududa District, Eastern Region, Uganda. Google Maps. Retrieved on 7 July 2016. 